\title{
Effects of Government's Policy in Stock Price: A Case of Nepse
}

Ganesh Prasad Niraula

Department of Management - Patan Multiple Campus - Lalitpur - Nepal

Correspondence Email: ganesh.niraula@pmc.tu.edu.np

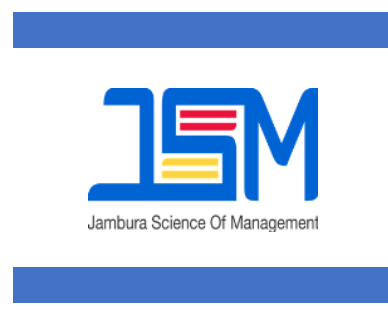

JSM

Volume 4

Number 1

January 2022

Received on 2 Nov 2021

Revised on 4 Nov 2021

Accepted on 4 Nov 2021

The journal allows the

authors to hold the copyright

without restrictions and

allow the authors to retain

publishing rights without

restrictions. Authors retain

copyright and grant the

journal right of first

publication with the work

simultaneously licensed

under a creative commons

attribution 4.0 international

license.

(c) (1)

DOI: 10.37479

\section{ABSTRACT}

Purpose: The purpose of this study is to find out the relationship of government's policy on the price movement of Nepal stock exchange (NEPSE)

Design/Methodology/Approarch: This study followed a case study research design, because it offers a deeper perspective and clearer understanding of the stock price movement of Nepalese joint venture banks. The sample size of this study consists of five joint venture commercial Banks, economic analysis and survey reports conducted by central bank of Nepal (Nepal Rastra Bank).The judgmental sampling method has been applied for selection of joint venture banks. The study was totally based on secondary data. in order to make proper analysis descriptive and inferential statistics were used using SPSS software version 26.

Findings: The finding of this study revealed that the GDP and import are inversely associated with stock price movement and CRR, export, interest rate and inflation are positively associated with stock price movement. Further, it is found that the macroeconomic variables are key factors to determine the Nepalese stock price movement. More importantly, stock market has been found to respond significantly to changes in the government policy. It is recommended that CRR, EXPORT, INTEREST RATE and INFLATION are major factors which largely affect the stock price movement of NEPSE. GDP and IMPORT are not compliance with the stock price movement as they produce negative association with the stocks volatility.

Keywords: GDP; Fiscal Policy; Monetary Policy; Import; Export

\section{INTRODUCTION}

Government policy affects stock price movement directly or indirectly. Government policies like fiscal policy that determines economic direction. It is related to the level of taxation and government spending in order to influence the aggregate demand and the level of economic activity. Government uses fiscal policy to influence the economy by adjusting revenue, spending, inflation and employment.(Bhandari 2020) it contains different macroeconomic variables such as gross domestic product, income distribution, stages of economic development (least developed economy, developing economy and developed economy) economic condition,( economic 
strengths and weaknesses) per capita income, economic growth rate and trade cycle. Major macro-economic variables which directly affects the movement of stock price. If a nation has strong economy that can be reflected as a stability in the price of share market as we know share market is known to be a mirror of national economy of a country.

Government policy like monetary policy is the prime factor for the price movement of NEPSE. It is concerned with monetary system of a country. The system is formulated and implemented by central bank. It focuses on management of money supply and interest rate. Monetary policy is used by government of a country to achieve macroeconomic objectives like price stability, economic growth, balance of payment stability and full employment.(Bhandari 2020) In addition to these factors, it also includes cash reserve ratio and statutory liquidity ratio etc.

The government of Nepal has issued new commerce policy in 2015. This policy is intended to reduce trade deficit through the utilization of opportunities provided by world trade organization incorporating issues including developing harmony between commerce policy and Nepal trade integration strategy, enhancing supply related capacity, increasing production and productivity, protecting and promoting service, trade and intellectual property, supporting the mainstreaming trade, making arrangement for monitoring corporate social responsibility.(Bhandari 2020. However the commerce policy has been envisaged to construct board of trade at central level to formulate and implement trade related policies with active participation of private sector.

Import and export business affect the capital market of a country. Exporting goods and service to foreign countries attributes to foreign currency earning, hence it provides strength to local industries that leads to increase in the price of shares in the domestic market and more dependency in import leads to decrease in local companies' performance and share prices. Nepal mainly exports carpets, beverage, textile, tea and plastic. Its main export partners include India, the US, Bangladesh and Germany. Nepal mainly imports fuel, apparel, gold, iron and steel, machinery and equipment. India, China, the UAE, Indonesia and Thailand are main import partners.

\section{Review of Literature}

Ojha (2019) describes that any new information relevant to the market is spontaneously reflected in the stock prices. He tested some hypotheses and found that past prices can not have any predictive power for future prices. He further added that the change in future prices depends only on arrival of new information that was unpredictable today, it is based on surprise information.

Hsing (2013) finds that Poland's stock market index is not affected by the ratio of government deficits or debt to GDP and is negatively influenced by the money market rate. The stock index and the ratio of 
M3 to GDP show a quadratic relationship with a critical value of $46.03 \%$, suggesting that they have a positive relationship if the M3/GDP ratio is less than $46.03 \%$ and a negative relationship if the M3/GDP ratio is greater than $46.03 \%$. Furthermore, Poland's stock index is positively associated with industrial production and stock market performance in Germany and the U.S. and negatively affected by the nominal effective exchange rate and the inflation rate.

Reddy (2012) finds that the market reacts differently to various factors ranging from economic political, and socio-cultural scenarios. He further adds the stock prices of quoted companies are affected either positively or negatively by a number of factors occurring within or without the economic system. And finally he found that while a reduction in interest and inflation rate resulted in increased stock prices, increased RGDP has a positive impact. Government should therefore implement policies that will reduce inflation rate and improve the standard of living of its citizens. The interest rate should be made moderate so as to encourage investment and transaction.

Ioannidis and Kontonikas (2006). Studies the impact of monetary policy on stock returns in thirteen countries over the period 19722002.They found that monetary policy shifts significantly affect stock returns, thereby supporting the notion of monetary policy transmission via the stock market.Finally,they took into account the increasing co-movement among international stock markets and the results remains unchanged.

Ogutu (2011) finds that GDP would lead to increase in stock market performance. He further recommends that any investor who wants to invest by buying or selling shares in the stock market, should closely monitor the GDP performance to determine whether it's viable to invest then Investors should buy shares when GDP is performing poorly and sell when the GDP performs well for them to have valuable investments.

Salvatore (2012) finds that the dynamics of the interest rate consistent with price stability requires a response to stock-price changes that depends on the shock driving them: a supply shock (e.g. productivity) does not require an additional, dedicated response relative to the standard Representative-Agent framework, while a demand shock does. He further adds when showing that implementing the flexibleprice allocation by means of an interest-rate rule that reacts to deviations of the stock-price level from the flexible-price equilibrium incurs risks of endogenous instability that are the higher the less profitable on average equity shares.

Vanitha et al (2013). Set their objective to find the impact of change in CRR and Reverse repo rate on stock price of banking companies listed in national stock exchange and found that the security prices reacted to the announcements of reverse repo rate and cash reserve ratio. 
Segal (2021) finds that excessive import of merchandise goods would lead to decrease price in the share market according to her apathy on using domestic products can lead local investors to invest in foreign companies which lead to decrease in the share prices of local market but in the contrast increasing in export leads to increase in domestic index of share market and vice versa for decreasing export to foreign countries.

\section{METHODS}

\section{Nature and Sources of Data}

This study has utilized secondary sources of data. The predictive power of firm specific fundamental and macro-economic variables related to government policy in explaining stock price movement have been tested using secondary sources of data.

The study mainly focused on secondary data, the data from Nepal stock exchange (NEPSE), and security board of Nepal (SEBON) and Nepal Ratra Bank's web sites for collecting data. The study period covers from the fiscal year 2016 to 2020

Using statistical tools, the data collected from the secondary sources were analyzed and the results were presented. The analysis begins with the study of secondary data using the SPSS. The data obtained from the different websites were coded into the SPSS version 18 worksheet and tabulated. To test the reliability of scaled products, the alpha coefficient of, correlation and hypothesis have been used for inferential analysis.



Figure 1. Conceptual Framework

This study consists of six independent variables; GDP.Inflation.CRR, Interest Rate, Import and Export. Meanwhile, it has one dependent variable which is the research variable stock price movement. This conceptual framework is explained in previous study Ojha (2019), Hsing (2013), Reddy (2012), Ioannidis and Kontonikas (2006), Ogutu (2011), Salvatore (2012), Vanitha et al (2013) and Segal (2021). 


\section{Hypotheses Formulation}

H1: There is positive relationship between GDP and stock price movement.

$\mathrm{H} 2$ : There is negative relationship between inflation and stock price movement.

H3: There is negative relationship between CRR and stock price movement.

H4: There is negative relationship between interest rate and stock price movement.

H5: There is negative relationship between import and stock price movement.

H6: There is positive relationship between export and stock price movement.

\section{RESULTS AND DISCUSSION}

\section{Inferential Statistics}

Inferential statistics are procedures used which allow researchers to infer or generalize observations made with samples to the larger population from which they were selected. This result provide new information through prediction and generalize based on samples.

\section{Correlation Analysis}

Correlation between Independent and Dependent variables is shown in Table 1

Tabel 1. The Correlation Analysis Results

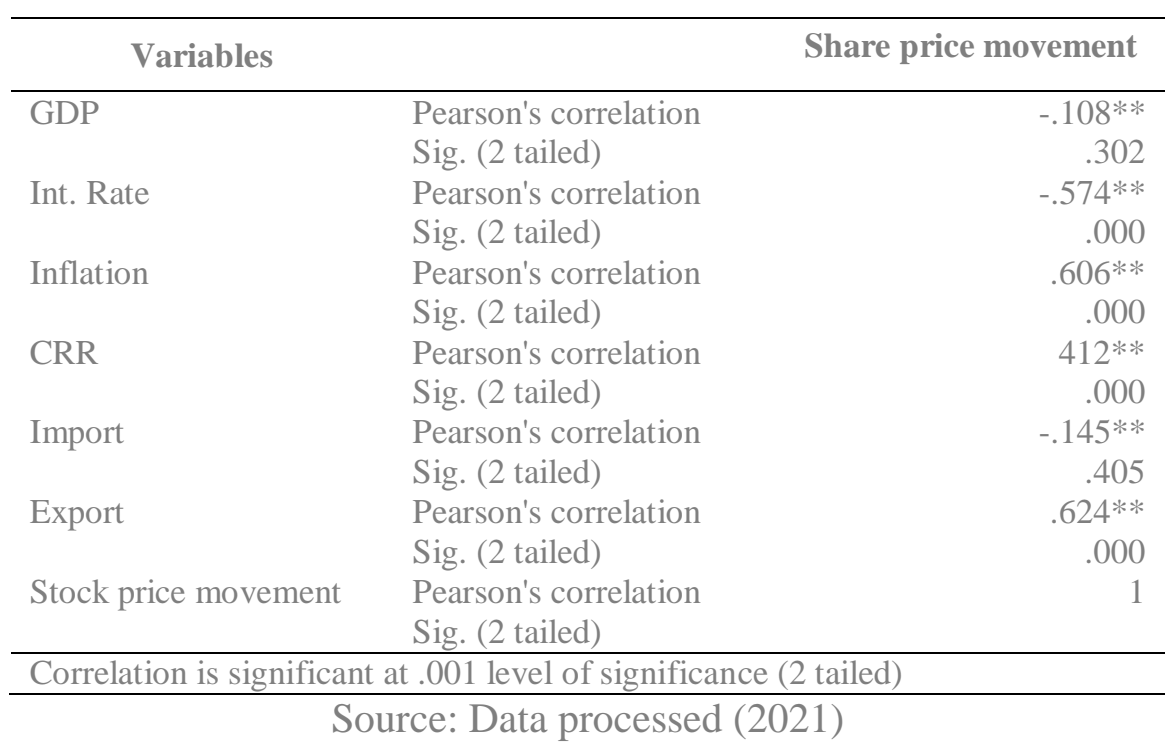

Table 1 shows that the Pearson Correlation coefficient between the independent variables GDP, Inflation, CRR, Interest Rate, Export and Import and dependents variable Stock Price Movement are-.108,$.574, .606, .412,-.145$ and .624 respectively which implies that the three variables are positively correlated and three are negatively correlated. There are positive correlation between inflation CRR and 
export with the share price movement and negative correlation between GDP, interest rate and import.The significance was measured at $1 \%$ significance level.

\section{Correlation Coefficient of Variables}

Tabel 2. Correlation Coefficient of Variables

\begin{tabular}{|c|c|c|c|c|c|c|c|}
\hline & $\begin{array}{l}\text { Share } \\
\text { Price }\end{array}$ & Gdp & $\mathrm{Crr}$ & Export & Import & $\begin{array}{l}\text { Int. } \\
\text { Rate }\end{array}$ & Inf \\
\hline Share price & 1 & & & & & & \\
\hline Gdp & -0.179 & 1 & & & & & \\
\hline $\mathrm{Crr}$ & 0.412 & 0.521 & 1 & & & & \\
\hline Export & -0.624 & 0.626 & -0.289 & 1 & & & \\
\hline Import & -0.145 & 0.916 & 0.647 & 0.445 & 1 & & \\
\hline Int. Rate & -0.573 & 0.767 & -0.015 & 0.947 & 0.676 & 1 & \\
\hline Inf. & 0.605 & -0.708 & 0.120 & -0.906 & -0.672 & -0.942 & 1 \\
\hline
\end{tabular}

The above table shows that the relationship between share price movement and GDP is negative, the relationship between CRR and share price movement is positive, the relationship between export and share price is negative, the relationship between import and share price is negative, the relationship between interest rate and share price is negative and the relationship between inflation and share price is positive. Similarly the relationship between CRR and GDP is positive, the relationship between export and CRR is negative, the relationship between import and export is positive, the relationship between interest rate and import is positive and the relationship between inflation and interest rate is negative.

\section{CONCLUSION}

The objective of this study is to examine the effects of government policy in stock price movement of Nepse. Six research hypotheses were formulated and tested to identify the effects of six dimensions (GDP, Inflation, CRR, Interest Rate, Import and Export) considering stock price movement. From the significant value taken from the sample, the significance of the hypothesis among the variables is also evaluated. It embraces that two of the independent variables are negatively correlated with stock price movement and rest of the variables are positively correlated. To address the six study hypotheses, the correlation findings were used. The Pearson coefficient of correlation between all six different variables and the dependent variable (stock price movement) was done, which implies that among six variables (GDP and import are inversely correlated and rest of the variables are positively correlated with stock price movement at 5\% significance level.

This research clearly indicates that CRR, Export, Interest Rate and Inflation are major factors which largely affect the stock price movement of Nepse. GDP and Import are not compliance with the stock price movement as they produce negative association with the 
stocks volatility. This study contributes $66.66 \%$ on the variables of stock price movement of Nepse so this research is consistent with the above studies.

\section{RECOMMENDATION}

As mentioned in the scope of this study, not adequate researches were found in the price movement of Nepal stock exchange. This study limited itself to the joint venture commercial banks of Nepal and the macroeconomic variables conducted by the central bank of Nepal. The sample size of joint venture banks could not be sufficient to predict the stock price movement of NEPSE. This study is dependent on data collected from the financial reports of concerned joint venture banks and the economic survey report of Nepal Rastra Bank. Further study may be conducted by using qualitative data and tools like questionnaire, survey, interview and observation. It is recommended that further studies are needed to address the inconsistencies that stands at $33.34 \%$ in future. Many other samples from different sub index sectors of Nepal stock exchange can be taken as sample to know the real price movement of NEPSE.

\section{REFERENCES}

Bhandari, D. R. (2020). Business environment in Nepal. Kathmandu: Asmita publishers and distributors, PP53.

Bhandari, D. R. (2020).Business environment in Nepal. Kathmandu: Asmita publishers and distributors, PP596.

Hsing, Y. (2013). Effects of Fiscal Policy and Monetary Policy on the Stock Market in Poland. Economies, no 1, pp 19-25.

Ioannidis C, and Kontonikas, A. (2006). Monetary Policy and the Stock Market: Some International evidence. Research gate journal.

Nistico, S. (2012). Monetary policy and stock-price dynamics in a DSGE framework. Journal of Macroeconomics.Volume 34, issue 1, PP 126-146

Ogutu, C. O. (2011). The relationship between the GDP and share price movement at the Nairobi Stocks Exchange. An unpublished master's dissertation, University of Nairobi, Kenya.

Ojha, B. R. (2019). Causal impact of government policy in stock market of Nepal. Management Dynamics, Shankardev Campus, Kathmandu. Vol. 22, No. 1: pp 69-78.

Reddy, D.V.L. (2012). Impact Of Inflation And Gdp On Stock Market Returns In India: International Journal of Advanced Research in Management and Social Sciences. Vol. 1, No. 6, pp. 120136.

S. Vanitha, S., NageswarI, P. and Shrinivasan, P. (2013). Impact of reverse repo rate and cash reserve ratio in National stock 
exchange (NSE). International Journal of Management and Business Studies. Vol. 3 (1), pp. 072- 081. 